\title{
INSTITUTIONAL SURROUNDING OF INNOVATIVE ACTIVITY - BASED ON OPINIONS OF WOMEN AND MEN ENGAGED IN THE PROCESS OF INNOVATION
}

\author{
Ewa Okoń-Horodyńska*, Anna Zachorowska-Mazurkiewicz**, \\ Rafał Wisła***, Tomasz Sierotowicz****
}

\begin{abstract}
Background. Innovations are one of the sources of economic growth and long-term development. Therefore it is important to consider which factors form, influence, and promote innovative activities.

Research aims. The main objective of the article is to identify the differences in opinions between men and women employed in innovative enterprises regarding solutions promoting innovative activities, which should be taken into account, while public policy is designed.

Methodology. In order to reach this objective, a survey concerning the institutional context of the process of innovation was conducted among research personnel in companies that received public financial support for their innovative activities. In order to group different institutional solutions influencing women and men, the cluster analysis was used.

Key findings. The results of the study show that institutional solutions promoting innovative activities are not gender neutral, indicating that there are both similarities and differences in women's and men's opinions, as well as in opinions regarding the solutions promoting innovative activities by women and men. The work environment is perceived as the most powerful determinant of the process of innovation. However, a combination of innovation policy and public actions for equality also plays a role in the development of innovations.
\end{abstract}

Keywords: gender, innovation, innovation process, innovative enterprise, institutional environment.

\footnotetext{
* Jagiellonian University, Poland. E-mail: ewa.okon-horodynska@uj.edu.pl

** Jagiellonian University, Poland. E-mail: anna.zachorowska@uj.edu.pl

*** Jagiellonian University, Poland. E-mail: rafal.wisla@uj.edu.pl

***** Jagiellonian University, Poland. E-mail: tsierotowicz@uj.edu.pl
} 


\section{INTRODUCTION*}

Innovations are one of the sources of economic growth and long-term development (Schumpeter, 1912; Alsos et al., 2013; Hunt et al., 2013; Shane, 2009). Therefore, it is important to consider which factors influence and promote innovative activities. Since innovations are important for economic prosperity, it is worth promoting innovative activities in the whole society, among men as well as women. Thus, the paper focuses on women's and men's opinions concerning the institutional context that promotes innovative activities.

The main objective of the paper is to identify statistically significant differences in opinions between men and women employed in Polish innovative enterprises regarding solutions promoting innovative activities, which should be taken into account, while public policy is designed. To study this relationship the data was gathered in a survey conducted among research personnel in Polish innovative enterprises. The survey was conducted between 15 th October and 15th December, $2015 . * *$

The structure of the study is as follows. Section 1 presents a literature review in relation to the links between innovations, gender, and institutional context. Section 2 describes the methodology and primary data used to achieve the main objective of the study. The following section is focused on the results of the survey concerning opinions regarding the institutional solutions promoting innovative activities both by women and men. This section is followed by the discussion and conclusions, and by the section devoted to identifying further research topics.

" This work is supported by the National Centre for Research and Development (NCBiR) under Grant No. Pol-Nor/200588/60/2013 "Innovative Gender as a New Source of Progress" by the Polish-Norwegian Research Programme.

** The article is a part of a larger project on "Innovative Gender" as a New Source of Progress (InnoGend). This large project aims to answer the question of whether gender translates into creativity and innovation, what the symptoms are, and whether by supporting creativity and innovation processes state policy actually takes all these aspects into account. 


\section{LITERATURE REVIEW}

\section{Women, men, and innovation}

Empirical results of international comparative studies show a clear regularity in the lesser involvement of women in the creation of: scientific knowledge (Larivière et al., 2013), and industrial knowledge (Bunker-Whittington \& Smith-Doerr, 2005; Frietsch et al., 2008; Frietsch et al., 2009). According to official statistics, women are somewhat underrepresented in the fields of creativity, innovation, invention, and scientific achievements. This is reflected, inter alia, by statistics for the Nobel Prize. Women Nobel Prize winners are less than 5\% of the total awarded this prize. Men dominate decisively. There is a slightly more favourable image according to data on the number of double Nobel Prizes. This double prize has been awarded twice to four scientists so far, including one woman - the Pole Maria Curie-Skłodowska (Nobel Prize for Physics in 1903 for her discovery of radioactivity, and Nobel Prize for Chemistry in 1911 for obtaining pure radium). However, in assessing the true role of women in the field of creativity we cannot in any event settle only on the figures (Okon-Horodyńska, 2015, p. 243). For example, Eriksson (2014) conducted an interesting study concerning how gender perspective contributes to or function as a driving force for innovation. She concludes that gender is a driving force of innovation (p. 175).

However, the phenomenon of gender is not sufficiently utilised in the context of innovation. Research in the area of women and innovation is not isolated, and concerns demonstrating best practice in implementing innovations by women and men in various areas of the economy, e.g. agriculture (Gonet, 2015), pedagogy (Dudel et al., 2014), high technologies (PARP, 2007), STEM (Beede et al., 2011), and in science (Larivière et al., 2013; Okoń-Horodyńska \& Zachorowska-Mazurkiewicz, 2015). Extensive research has also looked at other issues, such as the importance of innovation for strengthening the role of women in life and business (Malhotra et al., 2009), career paths in innovative companies (Galindo \& Ribeiro, 2012). There are also publications worthy of attention in which the authors describe European, national, and regional initiatives concerning gender equality, covering some issues related to innovation, entrepreneurship, e.g. in the Program Progress, 
Community Initiative Equal, the Program Platform of the Foundation for Polish Science, the program Lean in STEM Education Foundation from the Educational Perspective, the workshops Commercialization of Science Innovation and the contest Girls of the future.

A book edited by Okoń-Horodyńska and Zachorowska-Mazurkiewicz (2015), covers a broad range of topics discussing women's position in the economy, politics, science, as well as their patent activity. The latter was more broadly studied in Okon-Horodyńska et al. (2015), where innovative activity was studied taking into account the criterion of gender and identifying the directions and dynamics of change in the number of patent inventors in selected EU member states. An interesting regularity was discovered after the analysis of the results achieved. The patent activity of women in the leading EU countries in terms of obtaining patents included in the study increased significantly while the patent activity of men decreased in all these countries throughout the same period. This means that the role of women as inventors of patents, which form an important component of the innovative potential of the leading EU countries included in the study, systematically grew in the long term. This phenomenon, which was observed in the field of patent activity, has a significant impact on the innovative development of these economies. In the paper by Sierotowicz and Zachorowska-Mazurkiewicz (2016) a similar dynamic was considered for transition economies. The same data set was used, and the results show that in Poland the dynamics of growth in the number of men inventors of industrial property is higher than in the case of women inventors in the same period under study. In Poland there was actually a drop in the ratio of the number of women to the number of men inventors of industrial property in the business sector. This situation is the opposite of the one describing EU leading countries, where the ratio increased throughout the period analysed. It could be concluded that the role of women in the process of innovation is limited in the business sector in Poland. This limitation leads to the decreasing role of women inventors of industrial property in the business sector. This could also be a factor explaining the poor performance of Poland in terms of patents obtained. But more generally such a situation poses a question about the factors which may promote innovative activity among women and men in the economy.

There are few papers that address related issues of gender and innovations. For example, Foss et al. (2013, p. 301) states that research 
on gender leads to an assumption that innovation processes are gendered. They are gendered in the way, in which the masculine ideas are implemented to a greater degree than the feminine ones. The gender dimension is deeply embedded in the way we do science and develop innovations, influencing the entire process from the laboratory to the market. Østergaard et al. (2011) shows that the likelihood of introducing an innovation is greater in organisations in which the minority group has a critical mass to contribute to the innovation process, thus in a male-dominated organisation, gender has a moderating effect on the relationship between idea generation and implementation, because women employees will face more hurdles (Foss et al., 2013, p. 301). Hence, research shows that creative performance requires both masculine and feminine components (Jönsson \& Carlsson, 2000, cited by Foss et al., 2013, p. 304). A failure to integrate women into science and research could be reframed as an unacceptable waste of human resources (Abels, 2012, p. 187). These outcomes of previously conducted studies point at the necessity to look for ways of diversifying research personnel to include the underrepresented group, in the case of propose studies women. The analysis of opinions regarding solutions promoting innovative activity by women and men could provide some insights into this matter.

There are studies regarding gender in different contexts, some of which have been mentioned in the previous paragraphs, however the main focus of the article is the institutional surrounding serving the purpose of the promotion of innovative activities among women and men. Such narrowly defined purpose has not been extensively studied before.

\section{Institutional context}

Since economic activity takes place within an institutional framework (Freeman, 1987), it could be worth considering the institutional environment as one of the factors promoting innovative activities by women and men, providing in this way greater diversity among research personnel. The importance of institutions in economics has been claimed by institutional and other non-mainstream economists in the past. However, nowadays the idea that institutions matter, both in general and in particular, for growth and development is put forward even by mainstream economists. Thus institutional context is no longer deemed an exotic topic for economic analysis (Amable, 2000, p. 646). 
The economy, like society, represents a complex of institutions, formal and informal, ranging from the smallest, such as the family, to the largest and most comprehensive, namely the state (Chavance, 2009). Out of all the institutions, the formal ones have special status due to the fact that they try to stabilise certain equivalences between individuals and things in the form of rules. Among formal institutions the state holds a key position since state actions are based on normative representations of the "common good" for given societies (Storper, 2000 , p. 89). The state may help shape community preferences and social institutions (Whalen, 1996).

In such circumstances, a closer look at the institutional background of the innovation process is necessary in order to search for elements promoting innovative behaviour. It is also important to focus on the gender-dependent need for diversified institutional solutions that promote innovative activities by both women and men, since gender is a fundamental organising principle of institutions (Jacobsen, 2003).

It has to be underlined that the analysis of institutional context follows certain rules. Douglas North (1994) calls an "institutional matrix," a framework of interconnected institutions that together make up the rules of the economy (cited in Amable, 2000). Single institutions cannot be considered, since this may be misleading and may result in missing the genuine importance of institutions in the economy, which is combinative in nature (Amable, 2000, p. 647). Bruno Amable (2000, p. 650) presents the institutional context important for growth, where one of the sources of growth are innovations. According to him among influential institutions and organisation forms one may list: (1) the scientific system, (2) the education system, (3) firms and research laboratories, (4) the state, and (5) the financial intermediation system. And among economic policy instruments, one may find: (1) law on patents and intellectual property, (2) improving the relationships between science, technology, education, and the firms, (3) promotion of the availability of "patient" capital, (4) promotion of the availability of capital for risky investments, and (4) research and technology policy. This latter list illustrates well the connection between institutional context and the innovative activity of the enterprises. Institutions shape the behaviour of people, including those involved in the process of innovation, in this way creating the conditions for people to be creative and innovative. Hence, it is not well documented how institutional 
context influence gender, especially in the context of innovative activities. According to Womenable (2010, cited by Carrasco, 2014) there is a lack of information on how external factors may impact innovative behaviour by gender. The lack of such information could result in designing universal solutions that are directed towards women and men together. However, such solutions will not necessarily answer the needs of male and female research personnel. Carrasco (2014, p. 420) concluded her study with the statement that institutions matter for innovative activity by women. More specifically, she pointed at the necessity of gender perspective in innovative milieus, focusing on segregation in the job market, flexibility in the workplace, solutions that help to conciliate family and working lives, and differences in education and training. Under such circumstances, it seems rational to analyse institutional factors influencing innovative activity separately for women and men.

\section{METHODOLOGY}

The above discussion shows the importance of research concerning the gender perspective in the innovation process. In the study presented we have tried to verify whether there are differences between men and women regarding solutions promoting innovative activities, which should be taken into account, while designing public policy. To verify such an objective the following research questions were formulated: (1) what is the difference in women's and men's opinions regarding desired institutional solutions promoting innovative activities? (2) is it possible to use the same group of institutional solutions in order to support innovative activities both by women and men? There are two kinds of differences that have been analysed in the study. First opinions regarding solutions that promote innovative activities among women, and among men, second, the opinions that promote innovative activities as such formulated by women and by men. This analysis has been conducted in the following analytical fields: (1) solutions that in women's and men's opinions promote women's innovative activities; (2) solutions that in women's and men's opinions promote men's innovative activities; (3) solutions that in women's opinions promote innovative activities; and (4) solutions that in men's opinions promote innovative activities. 
The data used in the study was gathered in the survey conducted in the last quarter of 2015. In the questionnaire distributed among male and female personnel of companies that received public financial support for their innovative activities* two open questions concerning the institutional context were included. The respondents were asked to list solutions supporting innovative activities that were directed towards women, and a separate list for men. 582 questionnaires were collected, out of 1,168 companies, in two independent groups of women 294 questionnaires and men 288 questionnaires. The majority of respondents were people with higher education, both in the case of women and men. In the group of women, age ranging from 18-64 years $(\mathrm{M}=33, \mathrm{SD}=7.7), 86.7 \%$ of women participants are characterised by higher education. In the group of men, age ranging from 18-65 years $(\mathrm{M}=36, \mathrm{SD}=9.3), 87.8 \%$ of men participants have a higher education diploma. The respondents were men and women employed in the Polish enterprise sector involved in different ways in the process of innovation. Each respondent represents one company covered by the research. They gave 3,832 answers, which consist of 1,665 unique solutions. The participants provided broad solutions in the open question. They pointed out up to 5 solutions that seemed important to them. This is the reason why there are sometimes the same answers given by multiple respondents and they had to be put in order and grouped. Since there is no universally accepted solution for ordering and grouping of this kind of responses for the research analysis, they have been organised into groups based on the content and meaning of each unique solutions. Based on these criteria the broad solutions bring 15 separate groups. Each group contained homogenous solutions. Hence, the scope of solutions highlighted by the respondents is illustrated by all 15 groups of answers. Groups differ between each other based on the meaning of homogenous solutions and allow to use the classic cluster analysis in order to answer the research problem and discover differences in women's and men's answers. The 15 groups are as follows: (1) work environment, (2) personal characteristics, (3) competences, (4) attitudes

\footnotetext{
" Beneficiaries of the Operational Programme Innovative Economy 2007-2013 for actions: 1.4 (Support for targeted projects), 4.1 (Support for implementation of results of R\&D work), 4.2 (Stimulating R\&D activities in enterprises and support in the field of industrial design), and 5.4 (Intellectual Property Management), a total of 1,168 selected companies. Participation in this programme proves unavoidably that these companies develop innovation at the operational level, which also means that the innovation process is provided and not managed occasionally and can be considered in the long term.
} 
and values, (5) roles and behaviour, (6) innovation policy, (7) tax policy, (8) educational policy, (9) public actions promoting equality, (10) public promotion of creativity, (11) other public policies, (12) external cooperation of the company, (13) gender does not matter, (14) lack of ready solutions, and (15) lack of opinion. Because 15 groups contain various answers not only solutions related to the research area, such as groups 14 or 15 , it was necessary to select from them groups that have been used in a further analysis.

From the groups distinguished above, 6 concerning institutional context (6-11) and 2 concerning the companies ( 1 and 12) have been chosen for further analysis. The respondents provided the solutions, however it needs to be stressed that the classification of particular solutions has been done by the authors. These eight groups consist of 3,361 responses, which is $88 \%$ of all responses indicated by respondents and also contains all 1,466 unique solutions covered by the research subject. These eight groups have been analysed using the cluster analysis.

The eight groups containing the homogenous solutions can be organised into clusters according to women's and men's responses, as well as to responses by women and men together. In order to discover differences and similarities between women and men the cluster analysis was used for all three samples (Everitt et al., 2011; Kaufman \& Rousseeuw, 2005; Grabiński et al., 1989; Grabiński, 1984). To calculate the distance between the numbers, indicated by respondents, of specified institutional solutions that support the innovation process from the perspective of the participation and role of women and the participation and role of men, the Euclidean metric has been used (equation 1):

$$
d_{(a, b)}=\sqrt{\sum_{k=1}^{p}\left(a_{k}-b_{k}\right)^{2}}=\left\|a_{k}-b_{k}\right\|_{2}
$$

where:

$d_{(a, b)}$ - the Euclidean distance between the centroids of each of the two clusters,

$p \quad-$ number of attributes, equal to the number of the variables which describe each group (here: $p=2$ ),

$a_{k}, b_{k}$ - successive group of solutions,

$k-$ - successive number of a group of solutions. 
The Euclidean metric has been used along with the Ward method (Deza \& Deza, 2009) (equation 2).

$$
\operatorname{dist}_{(a, b)}=\sqrt{\frac{2 n_{a} \times n_{b}}{\left(n_{a}+n_{b}\right)}} \times\left\|a_{k}-b_{k}\right\|_{2}
$$

where:

dist $_{(a, b)} \quad$ - the sum of squares measured as equivalent of distance measure,

$\left\|a_{k}-b_{k}\right\|_{2}-$ the Euclidean distance,

$a_{k}, b_{k} \quad$ - are the centroids of clusters a and $\mathrm{b}$,

$n_{a}, n_{b} \quad-$ are the number of elements (groups of solutions) in cluster $a$ and $b$.

The cluster analysis allows many metrics and methods to be selected, but only Euclidean and Ward provided the clear and most unambiguous results of the cluster analysis. As a result of these assignments and calculations a matrix of Euclidean distances has been obtained between 6 groups of institutional arrangements, taking into account an additional 2 groups of conditions internal to the entities researched. The cluster analysis has been subjected to the previously defined cases of indications.

The reason for selecting the cluster analysis was strictly related to the main objective of the research, which was to identify the existence of differences in men's and women's opinions regarding the process of innovation. The cluster analysis allows to identify statistically significant common and diversified groupings in there samples - women, men and women and men together. This should be taken into account in institutional solutions promoting innovativeness.

\section{RESULTS OF EMPIRICAL ANALYSIS}

Each respondent, a woman or a man, had the opportunity to indicate up to five most important support solutions for better participation in the innovation process taking place in the enterprises covered by the research.

Figure 1 represents the number of male and female responses related to the support solutions for women participating in an innovation 
process of enterprises covered by the research. The work environment was the most intensive area of response, in which 451 responses from women and 464 responses from men selected solutions in relation to the internal environment of the enterprises. The most common solutions for better participation of women in the innovation process, pointed out by women are: training and workshops; flexible working time; bonuses and other financial incentives; and promotion at work. The most common solutions for better participation of women in the innovation process, pointed out by men are: training and courses; flexible working time; bonuses, and a better atmosphere at work.

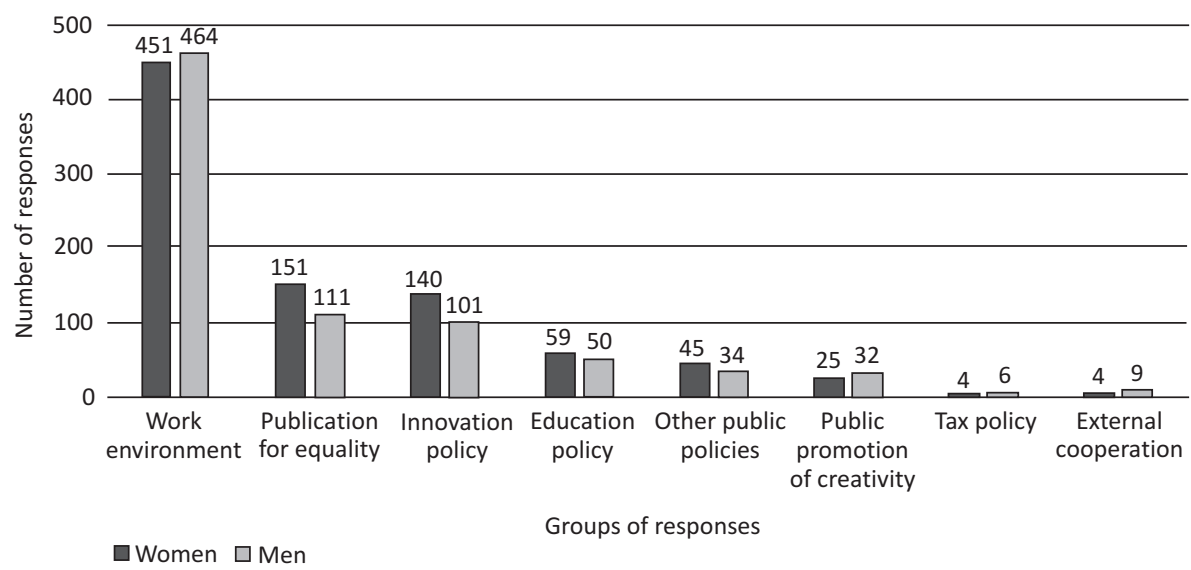

Figure 1. Solutions that in the women's and men's opinions promote women's innovative activities

Source: own elaboration

The first three solutions for women, pointed out by women and men are identical. However, men pointed out that women should create a better atmosphere in the workplace, because they are more influential in terms of soft competences. The fourth solution represents a gap between women's and men's approach to the workplace. From the men's point of view, women did not have sufficient courage concerning the atmosphere in the workplace. It seems that there is rather a struggle among women to get promotion at work faster, rather than concern about a work-effective atmosphere. In contradiction, from the women's point of view, it is more important to get promotion and be a manager rather than take care of the atmosphere in the workplace. This gap should be recognised more deeply in future research and play a part 
in the bundle of institutional solutions supporting innovative activities by both women and men.

Public actions for equality are the second most important area indicated, in which 151 responses by women and 111 responses by men selected solutions in relation to gender equality in the innovation process. The most frequent solutions by women for greater female participation in the innovation process by women are: support for equal rights for men and women; remote work (from home) and equal pay for women and men. The most frequent solutions by men for better female participation in the innovation process indicated by men are: support for equal rights for men and women; remote work (from home) and longer holidays.

The first two solutions for women, pointed out by both female and male respondents are identical. However, men pointed out that women should take longer holidays, while women preferred to be paid equally to men rather than take family holidays. This last solution represents a gap between women's and men's approach to the actions for equality and should be considered as a part of the gendered institutional support bundle for equality.

The third most important area pointed out was innovation policy, there were 140 responses from women and 101 responses from men indicating solutions related to the innovation process. The most common solutions for fuller women's participation in the innovation process indicated by women are: funding for innovative activities; participation in research, and supporting innovative attitudes and behaviours. The most common solutions for better women's participation in the innovation process indicated by men are: funding for innovative activities; participation in research, and patent information and activity.

The first two solutions for women, indicated by both female and male respondents, were identical. However, men pointed out that women should participate more in patent activities and related information, while women prefer to be supported in their innovative activities and behaviour. This last solution represents a gap between women's and men's approach to innovation policy. This could be a part of the gendered support institutional bundle of equality and lead to a synergy in women's and men's teamwork.

The last five groups represent opinions of less than $4 \%$ of responses. Therefore, they are not statistically significant. 
Figure 2 presents the number of women's and men's responses related to the support solutions for men participating in the innovation process in the enterprises covered by the research. The most intensive area of response is the work environment, 465 responses from women and 517 responses from men indicated solutions related to their place in the internal environment of the enterprises. The most common solutions for better participation by men in the innovation process indicated by women are: training and workshops; flexible working time; bonuses and other financial incentives and promotion at work. The most common solutions for fuller male participation in the innovation process indicated by men were: training and workshops; flexible working time; bonuses and better atmosphere at work.

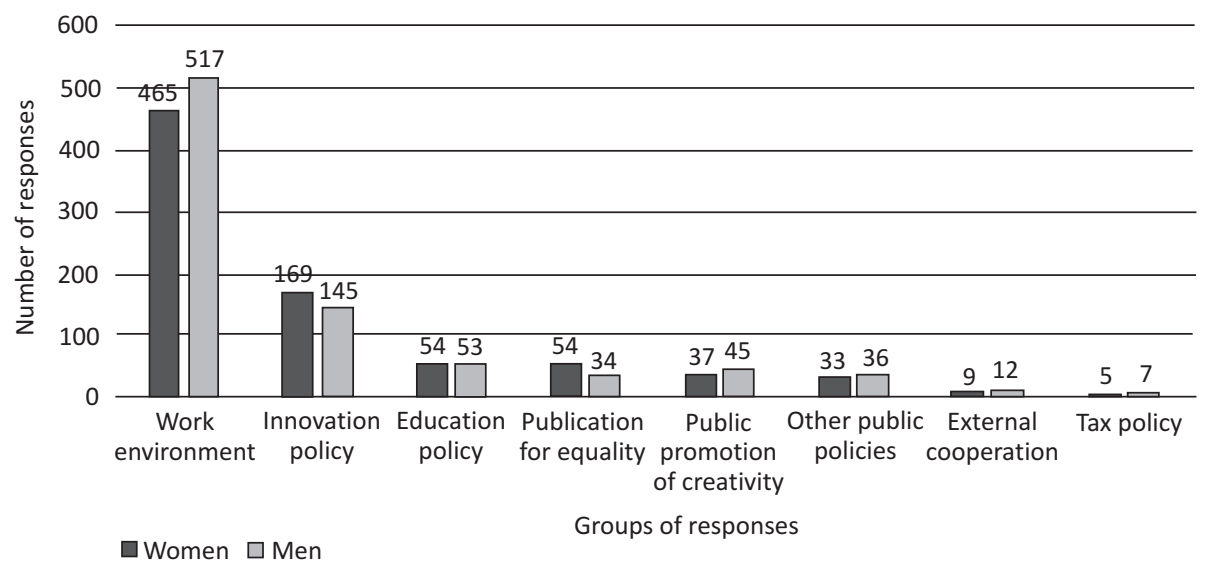

Figure 2. Solutions that in women's and men's opinions promote men's innovative activities

Source: own elaboration

This provides us with an identical set of solutions proposed for women by female and male respondents, presented in figure 1 . This result signifies an alignment between women and men in the assessment of work environment solutions for better participation in the innovation process. It also signifies that both women and men are deeply interested in harmonic cooperation. This could be a new addition to the gendered support institutional bundle of equality.

Innovation policy was the second most important area pointed out, 169 women's responses and 145 men's responses indicated solutions in relation to the innovation process. The most common solutions for 
better male participation in the innovation process indicated by women are: funding for innovative activities; access to new technologies and supporting innovative attitudes and behaviours. The most common solutions for fuller male participation in the innovation process indicated by men were: financial support provided by the EU and national authorities; access to new technologies, and training related to innovation development.

The first two solutions for men, pointed out by female and male respondents, are identical. However, women pointed out that men should be supported more in their innovative attitudes and behaviours, while men prefer to participate in training related to innovation development. This last solution represents a gap between women's and men's approaches to the actions for equality and should be a part in the gendered support institutional bundle of equality.

Education policy was the third most important area pointed out, with 54 women's responses and 53 men's responses pointing out solutions related to education in the innovation process. The most common solutions for better male participation in the innovation process indicated by women are: the development of intelligence among young people; equality between women and men in education, and early school education. The most common solutions for fuller male participation in the innovation process indicated by men are: the development of intelligence among young people; equality between women and men in education; and access to professional literature and books.

The first two solutions for women, pointed out by female and male respondents, are identical. However, women pointed out that men should participate in early school education in order to get better technical and professional preparation, while men prefer to have better access to professional literature and books. This last solution represents a gap between women's and men's approach to the innovation policy. It could be a part of the gender support package of equality and lead to the synergy in women's and men's teamwork.

The last five groups represent about 3\% of responses. Therefore, they are not significant from the research goal's point of view.

Both women and men respondents pointed out that the solutions described in figures 3 and 4 for the area of public action for equality refer in a greater extent to women than to men. Therefore, the solutions related to women, such as: support for equal rights for men and women; remote work (from home), and equal pay for women and men, should 
be subject to redefinition and correction in the innovation process rather than the solutions for men, which were: support for equal rights for men and women; remote work (from home) and longer holidays.

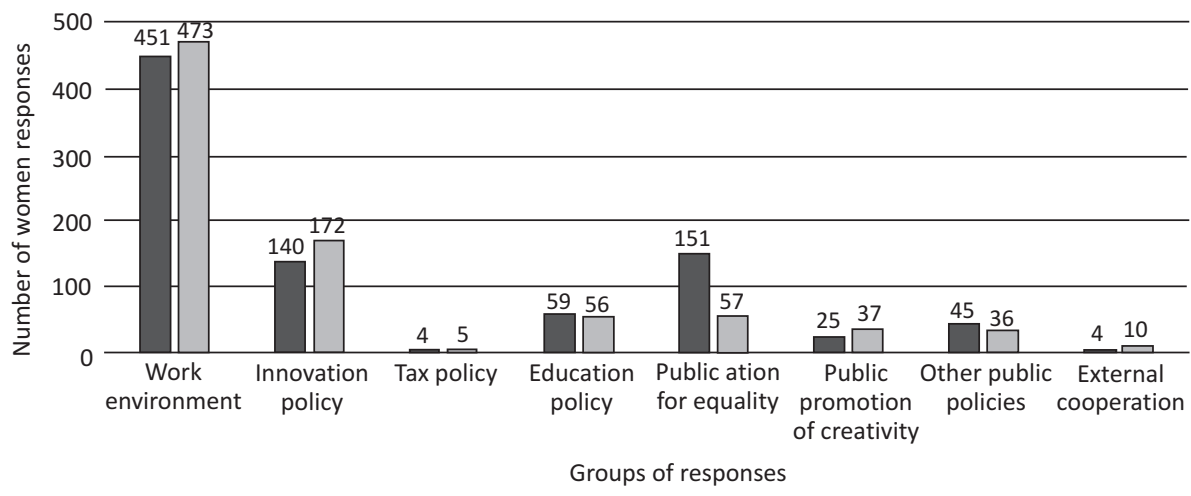

$\square$ Question A $\square$ Question B

Question A - Please provide 5 solutions supporting innovative activities dedicated to women.

Question B - Please provide 5 solutions supporting innovative activities dedicated to men.

Figure 3. Solutions that in women's opinions promote innovative activities Source: own elaboration

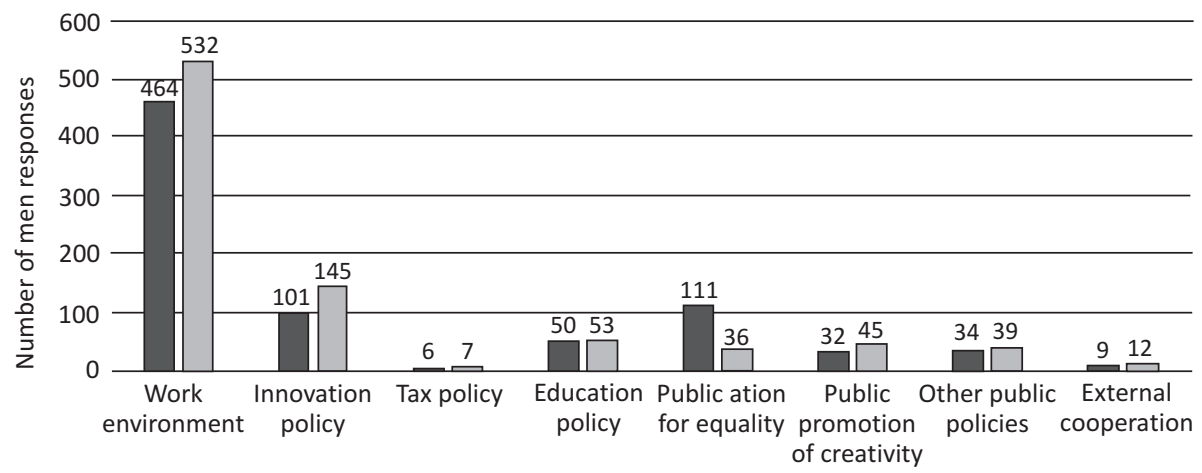

Question A $\square$ Question B

Groups of responses

Figure 4. Solutions that in men's opinions promote innovative activities Source: own elaboration.

This is another gap in the approach to teamwork, where teams consist of women and men. Hence, this gap should be researched more deeply to find the instruments that support women's and men's innovative activities. This gap also seems to have a synergy potential, 
which will be easier to achieve when the institutional solutions take into account such difference.

The cluster analysis results in dendrograms that are presented in the figures 6 to 9 . The presented dendrograms are interpreted according to Panek and Zwierzchowski (2013), Sneath and Sokal (1973), and Stanisz (2007).

Figure 5 presents the Euclidean distance between the responses of men and women to the question of the proposed recommendation to support the participation of women in the innovation process. In order to isolate clusters of institutional solutions (and the two internal conditions of the entities tested) the most similar to each other because of the variables that describe them, a division of the connectivity tree, taking into account a critical distance of 100 (Stanisz, 2007) was carried out. Reading figure 5 leads to the deletion of the following structures of clustering solutions for women indicated by the two groups of respondents.

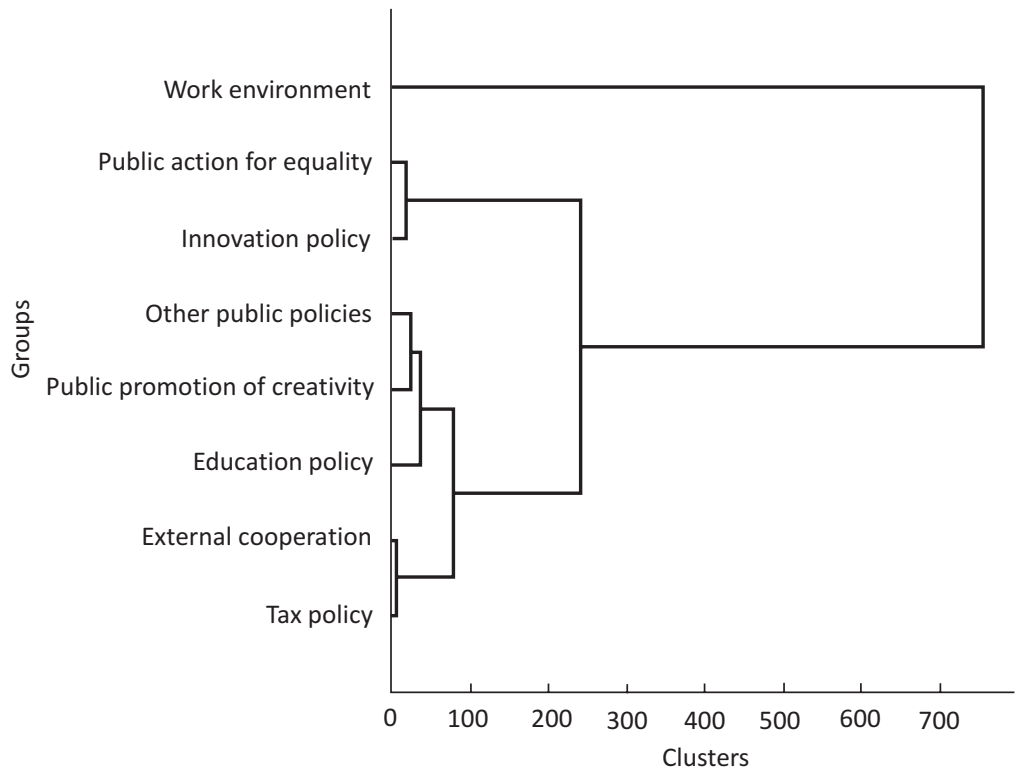

Figure 5. Cluster tree diagram for solutions that in women's and men's opinions promote women's innovative activities

Source: own elaboration

The first cluster identifies limitations and deficiencies in innovation policy and actions regarding the equality of women. The second group (collectively highlighted by women and men) focuses on the need to 
change education combined with the promotion of creativity and other policies leading to such solutions to take women more strongly into account. The third cluster is composed of tax policy and external cooperation of the subject entity. The fourth group is constituted by conditions that are typically internal to the study subjects in which there are no procedures and actions taking into account the gender factor - in this case the significance of gender and promotion of women. It should be included in the companies' internal bundle of equality.

The adoption of a critical value of 100 clearly allows the sum of purely institutional conditions (policies and instruments) to be separated from the autonomous entity-internal conditions (i.e. mostly best practice). It is these last conditions that were most frequently indicated in the context of the limitations and deficits in the context of the importance of women in the innovation process. In conclusion, such deficit should be taken into account of the institutional bundle of equity.

Figure 6 presents the differences between the responses of men and women to the question of the proposed recommendation and institutional arrangements to support the participation of men in the innovation process. In order to isolate clusters of institutional solutions the tree connections were divided, taking into account the critical value of a distance equal to 200 (Stanisz, 2007). Reading figure 6 leads to the identification of the following structure of clustering solutions for men indicated by the two groups of respondents.

The first major cluster consists of: education policy, equality action, and promotion of creativity combined with other forms of support for entrepreneurship and innovation activity. The same group also includes: tax incentives and the need for greater openness on the environment.

The abovementioned groups of solutions should further be the basis for the design of institutional solutions expected by research personnel from innovation policy. The results of the analysis also suggest that only together they form a distinct group of solutions to be studied more deeply in the context of their effectiveness. A separate group, as in the case of recommendations for women, is constituted by conditions and solutions directly related to the place and work environment the autonomous conditions of the economic entity, which should be included as tools of innovation policy.

Figure 7 presents the results of the cluster analysis of women's answers to the questions: on the proposed arrangements to support the activity in the innovation process. 


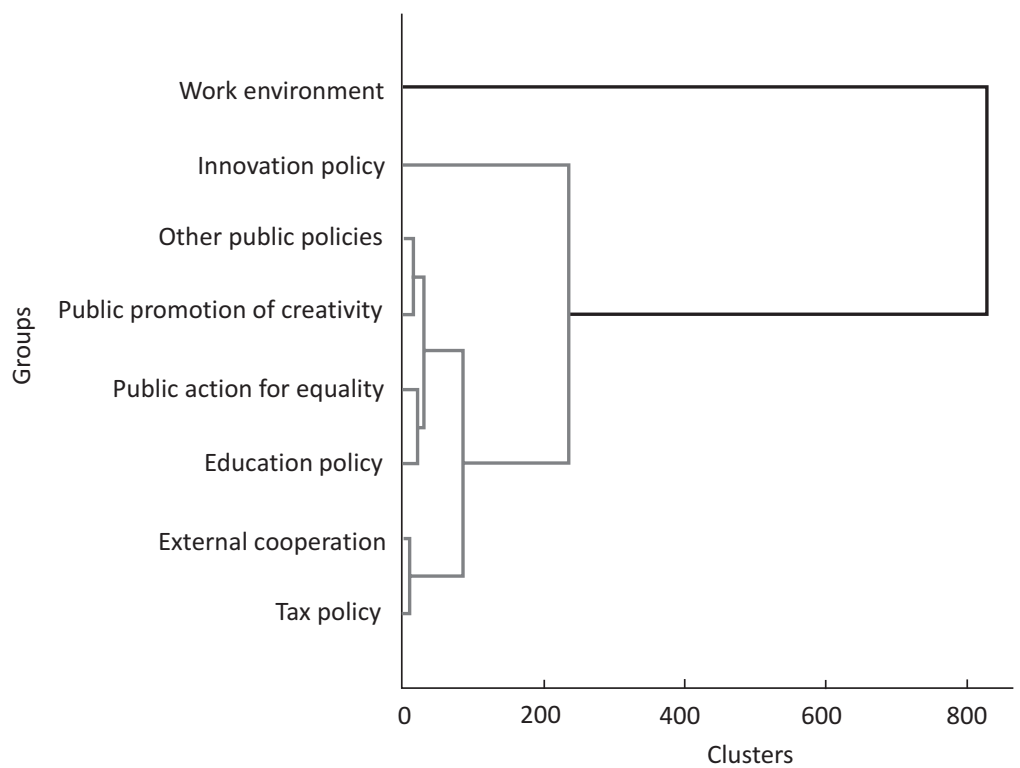

Figure 6. Cluster tree diagram for solutions that in women's and men's opinions promote men's innovative activities

Source: own elaboration

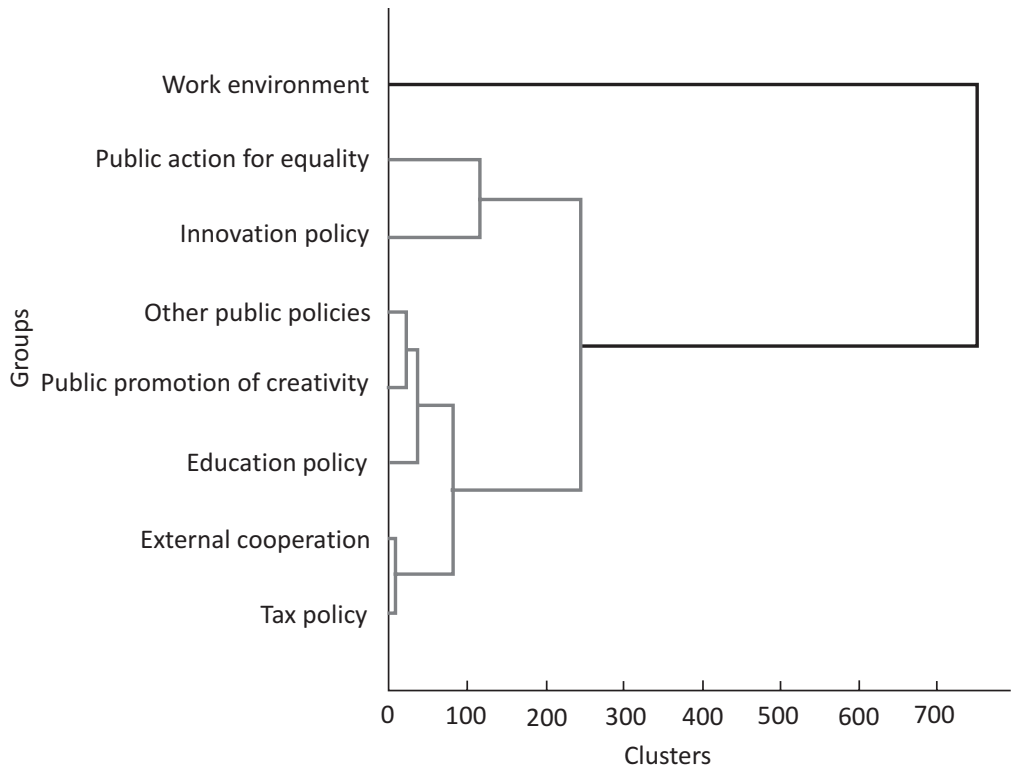

Figure 7. Cluster tree diagram for solutions that in women's opinions promote innovative activities

Source: own elaboration 
Figure 8 presents the responses of men to the questions on the proposed institutional arrangements to support innovative activities by both women and men.

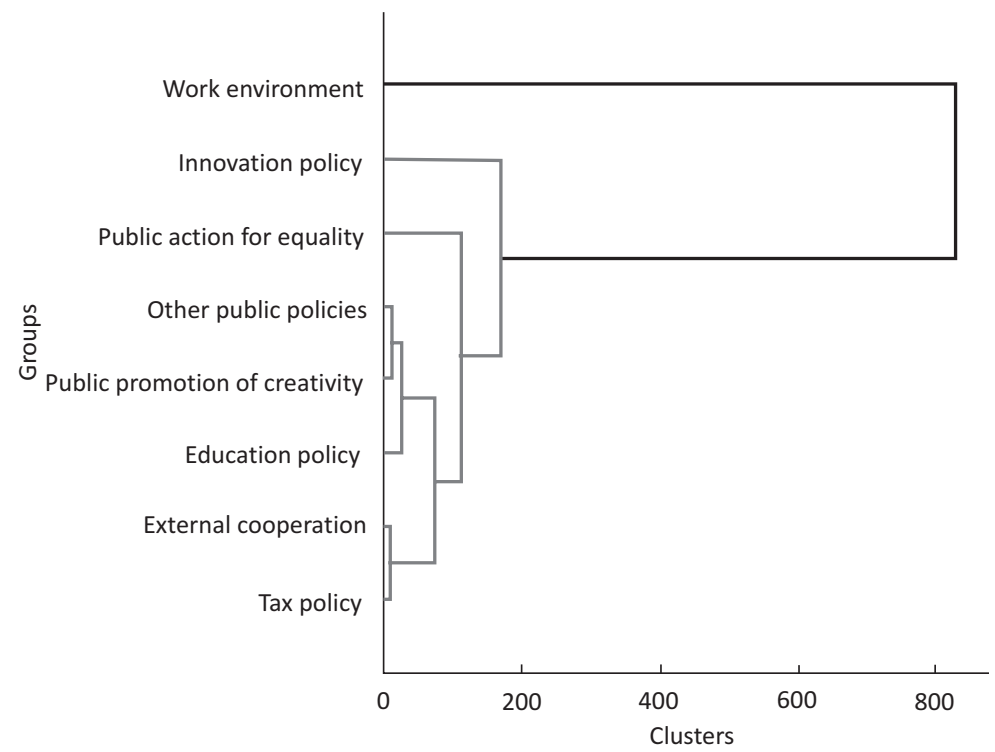

Figure 8. Cluster tree diagram for expected solutions that in men's opinions promote innovative activities

Source: own elaboration

Analysing the cluster tree diagrams presented in figures 7 and 8 together, we can see a similarity between recommendations formulated separately by women and men. Firstly, once again the importance of the work environment (working conditions, atmosphere, and non-financial incentives) as the determinant of the course and effects of the innovation process is confirmed. Secondly, in the context of activities supporting women's and men's innovative activities, innovation policy is always combined with equality measures in an institutional bundle.

\section{DISCUSSION AND CONCLUSIONS}

There is an apparent underrepresentation of women in the creation of innovations. The research results presented show differences in opinions concerning factors promoting innovative activities among women and men. Such an outcome is consistent with Abels (2012) 
and Foss et al. (2013) underlining the gender character of innovation processes. It is also an attempt to fill in the gap discovered by Womenable (2010) concerning the lack of information on how external factors impact innovative behaviour by gender. To prove that the heart of the innovation process has been reached in the research, the analysis of gender diversity in each of its stages has been conducted, accumulating the effects of diversity. And as Østergaard et al. (2011) and Jönsson and Carlsson (2000) write diversity, including gender diversity, is an important element in the promotion of innovative behaviour. The authors are trying to find out what incentives are needed to promote gender diversity in the area of creativity and innovation. The work environment and incentives coming from there are perceived by both women and men as crucial, but the significance of the state and the public policy is also noticed by the respondents. Thus, the main focus of the analysis is on institutional solutions, with one internal factor, namely work environment, that enables some comparison. The cluster analysis provides a picture consistent with North's (1994) and Amable's (2000) views concerning the institutional matrix. Particularly that it is crucial to consider a group of institutional solutions, not separate ones. The results concerning solutions promoting innovative activity are to some extent reflecting those obtained by Carrasco (2014), like flexibility in the workplace, but the role of the state in shaping community preferences is also underlined, and that reflects Whalen (1996) perspective that institutions matter. The analysis of institutional surrounding of innovative activity in the respondents' opinions - men and women employed in the Polish innovative enterprise sector - enables the following conclusions to be drawn: (1) the differences and similarities of women's and men's opinions regarding desired institutional solutions promoting innovative activities are present, and (2) the possibility of use of the same group of institutional solutions in order to support innovative activities both by women and men is considered.

- Of the 1,665 various proposals to increase the efficiency of the people involved in the process of innovation, half of the proposed solutions related to an organisation's environment (policies, support programs, regulatory changes). In the case of women the following were highlighted: (1) the need to change education combined with the promotion of creativity and other policies leading to such solutions to take women more strongly into account and (2) lack procedures and actions taking into 
account the gender factor - in this case the significance of gender and promotion of women. For men, these conditions are not important to the same extent. The direct determinants of the process of innovation (training, financing) are the most important. However, in general, the strongest determinant is a combination of innovation policy, and public actions for equality ( $34.25 \%$ women and $25.65 \%$ men). The expectations here regard a bundle of solutions, not single ones.

- Institutional solutions promoting innovative activities are not gender neutral, in the meaning that there are different institutional instruments needed for women and men.

- Among the policies analysed: innovation, education, taxation, and other public actions aimed at promoting gender equality and creativity, and internal conditions of economic entities, the most important in the innovation process are: work environment, and then public support in the form of a combined set of tools for innovation and equality policies. Tax policy and external cooperation of the company are perceived as the least important in terms of promoting innovative activities.

- The work environment (atmosphere, relationships, attitudes, incentives, rewards) is the most powerful determinant of the efficiency and effectiveness of the innovation process; $50.06 \%$ women and $57.20 \%$ of men indicated these conditions. (For this reason, it is necessary to conduct separate studies in this field). The most common solutions for better participation of women in the innovation process, pointed out by women are: training and workshops; flexible working time; bonuses and other financial incentives; and promotion at work. The most common solutions for better participation of women in the innovation process, pointed out by men are: training and courses; flexible working time; bonuses and better atmosphere at work. It is worth underlining that there is a strong need for cooperation, not competition; such cooperation may motivate women to get involved more in the process of innovation - especially technological.

The results of the analysis allowed to draw conclusions and reach the main objective of the article. We have identified statistically significant differences in opinions between men and women employed in innovative enterprises regarding solutions promoting innovative activities, which should be taken into account, while public policy is designed. 


\section{REFERENCES}

Abels, G. (2012). Research by, for and about Women: Gendering Science and Research Policy. In: G. Abels \& J.M. Mushaben (eds.), Gendering European Union. New Approaches to Old Democratic Deficits (pp. 187-207). Basingstoke: Palgrave Macmillan.

Alsos, G.A., Ljunggren, E. \& Hytti, U. (2013). Gender and innovation: state of the art and a research agenda. International Journal of Gender and Entrepreneurship, 5(3), 236-256.

Amable, B. (2000). Institutional complementarity and diversity of social systems of innovation and production. Review of International Political Economy, $7(4), 645-687$.

Beede, D., Julian, T., Langdon, D., McKittrick, G., Khan, B. \& Doms, M. (2011). Women in STEM. A Gender Gap to Innovation. U.S. Department of Commerce, Office of the Chief Economist, Washington. [Online] Retrieved from: http:// www.esa.doc.gov/sites/default/files/womeninstemagaptoinnovation8311.pdf (access: 12.03.2016).

Bunker Whittington, K. \& Smith-Doerr, L. (2005). Gender and commercial science

- Women's patenting in the life sciences. Journal of Technology Transfer, 30(4), 355-370.

Carrasco, I. (2014). Gender gap in innovation: an institutionalist explanation. Management Decision, 52(2), 410-424.

Chavance, B. (2009). Institutional Economics. London \& New York: Routledge. Degraff, J. \& Quinn, E. (2007). Leading Innovation. New York: McGraw - Hill. Deza, M. \& Deza E. (2009). Encyclopedia of Distance. Berlin: Sprnger-Verlag. Dudel, B., Kowalczuk-Walędziak, M., Łogwiniuk, K.M., Szorc, K. \& Wróblewska, U. (2014). Innowacje $w$ teorii i praktyce edukacyjnej. Białystok: Fundacja Centrum Transferu Wiedzy i Innowacji Społeczno-Pedagogicznych. [Online] Retrieved from: http://pedagogika.uwb.edu.pl/files/file/PDF/PUBLIKACJE/ Innowacje.pdf http://www://pedagogika.uwb.edu.pl/files/file/PDF/PUBLIKACJE/Innowacje.pdf (access: 23.03.2016).

Eriksson, A.F. (2014). A gender perspective as trigger and facilitator of innovation. International Journal of Gender and Entrepreneurship, 6(2), 163-180.

Everitt, B., Landau, S., Leese, M. \& Stahl, D. (2011). Cluster Analysis. West Sussex, UK: John Willey \& Sons.

Foss, L., Woll, K. \& Moilanen, M. (2013). Creativity and implementations of new ideas: do organizational structure, work environment and gender matter? International Journal of Gender and Entrepreneurship, 5(3), 298-322. 
Freeman, Ch. (1987). Technology and Economic Performance: Lessons from Japan. London: Printer Publisher.

Frietsch, R., Haller, I., Vrohlings, M. \& Grupp, H. (2008). Gender-specific patterns in patenting and publishing. Fraunhofer ISI Discussion Papers Innovation Systems and Policy Analysis, 16.

Frietsch, R., Haller, I., Funken-Vrohlings, M. \& Grupp, H. (2009). Gender-specific patterns in patenting and publishing. Research Policy, 38, 590-599.

Galindo, M.-A. \& Ribeiro D. (eds.) (2012). Women's Entrepreneurship and Economics. New Perspectives, Practices, and Policies, New York: Springer.

Gonet, D. (2015). Innowacyjność na przykładzie kobiet i mężczyzn prowadzących gospodarstwa rolne z gminy Bojanowo. Roczniki Naukowe Stowarzyszenia Ekonomistów Rolnictwa i Agrobiznesu, 5(17), 59-64.

Grabiński, T. (1984). Wielowymiarowa analiza porównawcza w badaniach dynamiki zjawisk ekonomicznych. Special issue: monographies, no. 61. Kraków: AE.

Grabiński, T., Wydymus, S. \& Zeliaś, A. (1989). Metody taksonomii numerycznej $w$ modelowaniu zjawisk społeczno-gospodarczych. Warszawa: PWN.

Hunt, J., Garant, J.-P., Herman, H. \& Munroe, D.J. (2013). Why are women underrepresented amongst patentees? Research Policy, 42, 831-843.

Jacobsen, J.P. (2003). Some Implications of the Feminist Project in Economics for Empirical Methodology. In: D.K. Barker \& E. Kuiper (eds.), Towards a Feminist Philosophy of Economics (pp. 89-103). London: Routledge.

Jaworek, M., Zachorowska-Mazurkiewicz, A. (2015). Gender as a category of analysis in the social sciences. In: E. Okoń-Hoodyńska \& A. Zachorowska-Mazurkiewicz (eds.), Statistical profiles of women's and men's status in the economy, science and society. Kraków: WUJ.

Jönsson, P. \& Carlsson, I. (2000). Androgyny and creativity: a study of the relationships between a balanced sex-role and creative function. Scandinavian Journal of Psychology, 41, 269-274.

Kaufman, L., Rousseeuw, P. (2005). Finding Groups in Data: An Introduction to Cluster Analysis. West Sussex: John Willey \& Sons.

Larivière, V., Ni, Ch., Gingras, Y., Cronin, B. \& Sugimoto C.R. (2013). Bibliometrics: Global gender disparities in science. Nature, 504, 211-213.

Malhotra, A., Schulte, J., Patel, P. \& Petesch, P. (2009). Innovation for Women's Empowerment and Gender Equality. Washington D.C.: The international Center for Research on Women (ICRW).

North, D. (1994). Institutions matter, mimeo. Washington University.

Okoń-Horodyńska, E. (2015). From Innovation to Innovative Gender. In: E. Okoń-Hoodyńska \& A. Zachorowska-Mazurkiewicz (eds.), Statistical 
profiles of women's and men's status in the economy, science and society (pp. 231-254). Kraków: WUJ.

Okoń-Hoodyńska, E. \& Zachorowska-Mazurkiewicz, A. (eds.) (2015). Statistical Profiles of Women's and Men's Status in the Economy, Science and Society. Kraków: WUJ.

Okoń-Horodyńska, E., Zachorowska-Mazurkiewicz, A., Sierotowicz, T. \& Wisła, R. (2015). Gender in the creation of intellectual property of the selected European Union countries. Economics and Sociology, 8(2), 11-25.

Okoń-Horodyńska, E. (2015). Regional Innovation Strategy as One of the Fields for Research in Innovative Gender (InnoGend). OPTIMUM. Studia Ekonomiczne, 5(77), 93-109.

Østergaard, C.R., Timmermans, B. \& Kristinsson, K. (2011). Does a different view create something new? The effect of employee diversity on innovation. Research Policy, 40(3), 500-510.

Panek, T., Zwierzchowski, J. (2013). Statystyczne metody wielowymiarowej analizy porównawczej. Teoria i zastosowania. Warszawa: Oficyna Wydawnicza SGH.

PARP (2007). Rola kobiet w innowacyjnej przedsiębiorczości wysokich technologii. Warszawa: ARC Rynek i Opinia, PARP.

Schumpeter, J.A. (1912). Theorie der wirtschaftlichen Entwicklung (2nd ed.). München und Leipzig: Duncker \& Humblot, 1926. English edition: The Theory of Economic Development, New York: Oxford University Press, 1934.

Shane, S. (2009). Why encouraging more people to become entrepreneurs is bad public policy. Small Business Economics, 33(2), 141-149.

Sneath, P.H.A. \& Sokal, R.R. (1973). Numerical Taxonomy. San Francisco: W.H. Freeman.

Stanisz, A. (2007). Przystęny kurs statystyki z zastosowaniem STATISTICA PL na przykładach z medycyny. Tom 3: Analizy wielowymiarowe. Kraków: StatSoft Polska.

Storper, M. (2000). Conventions and institutions: rethinking problems of state reform, governance and policy. In: L. Burlamaqui, A.C. Castro \& H.-J. Chang (eds.), Institutions and the Role of the State (pp. 73-102). Cheltenham: Edward Elgar.

Whalen, Ch.J. (1996). The institutional approach to political economy. In: F.E. Foldvary (ed.), Beyond Neoclassical Economics; Heterodox Approaches to Economic Theory (pp. 83-99). Cheltenham: Edward Elgar.

Womenable (2010). Innovation and Women's Entrepreneurship. An Exploration of Current Knowledge. United Nations Conference on Trade and Development, London.

Zachorowska-Mazurkiewicz, A. \& Sierotowicz, T. (2016). Women, men and creativity in business sector - comparative studies of leading EU and ECE countries. Journal of Research in Business, Economics and Management (JRBEM), 5(3), February, 609-624. 


\section{INSTYTUCJONALNE OTOCZENIE DZIAKALNOŚCI INNOWACYJNEJ W OPINIACH KOBIET I MĘŻCZYZN ZAANGAŻOWANYCH W PROCES INNOWACJI}

\section{Abstrakt}

Tło badań. Innowacje sa jednym za źródeł wzrostu gospodarczego i rozwoju w długim okresie czasu. Dlatego też istotne jest rozważenie, które czynniki kształtuja, wpływaja na i promuja działania innowacyjne.

Cel badań. Głównym celem artykułu jest rozpoznanie różnic w opiniach kobiet i mężczyzn zatrudnionych w innowacyjnych przedsiębiorstwach na temat rozwiązań promujących działania innowacyjne, które powinny zostać wzięte pod uwagę przy projektowaniu polityki państwa.

Metodologia. Aby osiagnąć ten cel, przeprowadzono ankietę dotyczącą kontekstu instytucjonalnego procesu innowacji wśród osób związanych z działalnością badawczą w przedsiębiorstwach, które otrzymały publiczne wsparcie finansowe swojej działalności innowacyjnej. W celu pogrupowania różnych rozwiązań instytucjonalnych wpływających na kobiety i mężczyzn wykorzystano analizę skupień.

Kluczowe wnioski. Wyniki badania pokazuja, że rozwiązania instytucjonalne promujace działania innowacyjne nie są neutralne ze względu na płeć, wskazujacc, że występują zarówno podobieństwa, jak i różnice w opiniach badanych kobiet i mężczyzn, jak i w opiniach dotyczacych rozwiąań promujących działalność innowacyjna wśród kobiet lub mężczyzn. Środowisko pracy jest postrzegane jako najsilniejsza determinanta procesu innowacji. Jednak połaczenie polityki innowacji i publicznych działań na rzecz równości płci również ma znaczenie w rozwoju innowacji.

Słowa kluczowe: płeć, innowacje, proces innowacji, innowacyjne przedsiębiorstwa, otoczenie instytucjonalne. 